\title{
INVESTIGATION OF PHYTOCHEMICAL CONSTITUENTS AND CARDIOPROTECTIVE ACTIVITY OF ETHANOL EXTRACT OF BEETROOT (Beta vulgaris. L) ON DOXORUBICIN INDUCED TOXICITY IN RAT
}

\author{
S. E. Nugraha ${ }^{1, *}$, Yuandani ${ }^{2}$, E. S. Nasution ${ }^{2}$ and R.A. Syahputra ${ }^{2}$ \\ ${ }^{1}$ Department of Pharmaceutical Biology, Faculty of Pharmacy, Universitas Sumatera Utara, \\ Medan 20155, Indonesia \\ ${ }^{2}$ Department of Pharmacology, Faculty of Pharmacy, Universitas Sumatera Utara, \\ Medan 20155, Indonesia \\ *E-mail: sonyekanugraha@usu.ac.id
}

\begin{abstract}
Doxorubicin is used extensively to treat cancer. Oxidative stress condition is closely related to doxorubicin therapy, which is characterized by the formation of lipid peroxidation which has the potential to cause cell damage and induced cardiotoxicity. This study was to determine the cardioprotective effect of beetroot ethanol extract on a rat induced by doxorubicin. As many as 30 Male white rats as weighing 180-200 grams were divided into six treatment groups. Group, I was the normal control group without treatment. Group II was a negative control group that only injected doxorubicin with a cumulative dose of $15 \mathrm{mg} / \mathrm{kgBW}$ for 15 days. Group III was the positive control group that treated by vitamin E $100 \mathrm{mg} / \mathrm{kgBW}$, Group IV-VI was the test group that treated by beetroot ethanol extract at doses of 100,200 and $400 \mathrm{mg} / \mathrm{kgBW}$ respectively for 15 days together with doxorubicin induction. The group treated with beetroot extract at a dose of $100 \mathrm{mg} / \mathrm{kgBW}$ could improve the condition of rat in all parameters including Creatine kinase-MB (CK-MB) level, Lactate Dehydrogenase (LDH) level and hematology profile and it was significantly different to the negative control $(\mathrm{p}<0.05)$. All parameters showed that the beetroot extract had a cardioprotective and it showed a dose-dependent manner. This research proves that the compound contained in beetroot ethanol extract has protective activity in rats that induced by doxorubicin.
\end{abstract}

Keywords: Doxorubicin, Beetroot, Cardioprotective, CK-MB, LDH, Hematology.

(C) RASĀYAN. All rights reserved

\section{INTRODUCTION}

Doxorubicin is anticancer that widely used as chemotherapy in cancer therapy. Doxorubicin is a cytotoxic anthracycline compound that was an isolated compound from Streptomyces peucetius var. Caesius ${ }^{1}$. Conditions of oxidative stress are closely related to doxorubicin therapy, which is characterized by the formation of lipid peroxidation which has the potential to cause cell damage ${ }^{2}$. Doxorubicin toxicity events can cause cell damage to organs such as the heart, kidneys and liver ${ }^{3}$.

The chemical structure of doxorubicin has the potential to form free radicals through various mechanisms. Quinone groups in the tetracyclic doxorubicin ring can release several superoxide radicals ${ }^{4}$. Doxorubicin metabolism also causes the formation of reactive aglycone metabolites and alcohol metabolites (doxorubicin-o-rubisinol), which can disturb the balance of Fe intracellular concentrations ${ }^{5}$. The administration of doxorubicin can increase the production of reactive oxygen species (ROS) and disrupt the balance of antioxidant defenses so that it could trigger a cell damage ${ }^{6}$. ROS is normally produced in the body by metabolic processes, to obstruct ROS, the body has a defense system against ROS by producing antioxidant enzymes such as superoxide dismutase, catalase, glutatione and others ${ }^{7}$. Excessive production of free radicals and reduced antioxidant defense systems will cause a cell damage.

There were many studies that prove the toxicity of doxorubicin to organs especially the heart organ ${ }^{8-11}$. It is necessary to have antioxidant supplementation to ward off free radicals from doxorubicin. One of the plants that have high antioxidant is one of beetroot (Beta vulgaris L.) ${ }^{12}$. Beetroot contains phytochemical

Rasayan J. Chem., 13(2), 973-978(2020)

http://dx.doi.org/10.31788/RJC.2020.1325601 
compounds such as terpenoids, alkaloids, flavonoids, steroids, tannins and saponins, and also betanin content which have high antioxidant effects ${ }^{13}$. Based on the description mentioned, this study was aimed to finding out the cardioprotective effects of beetroot ethanol extract (Beta vulgaris L. ) in doxorubicininduced toxicity in rat.

\section{Materials}

\section{EXPERIMENTAL}

Distilled water, beetroot, white male rats, ethanol 96\% (Merck), CMC-Na (Bratachem), vitamin e (Genero) and doxorubicin (Kalbe).

\section{Plant Collection and Extraction of Beetroot}

The plant samples were collected from a local market at the district of PB Selayang II, North Sumatera, Indonesia. The beetroot samples were authenticated by the Indonesian Institute of Science, Research Center of Biology, Bogor, Indonesia. An amount of $300 \mathrm{~g}$ dried beetroot was crushed then macerated in ethanol $96 \%$ for 5 days. Results evaporated with a rotary evaporator at a temperature of $\pm 50{ }^{\circ} \mathrm{C}$, then dried on a water bath. ${ }^{14}$

\section{Investigation of Phytochemical Constituents of Ethanol Extract of Beetroot}

Phytochemical constituents investigation were carried out on beetroot extract includes examining the chemical secondary metabolites such as saponins, flavonoids, tannins, alkaloids, glycosides, steroids and terpenoids. ${ }^{15-17}$

\section{Animals and Blood Sample}

The 30 male Wistar rats weighing 180-220 g were used in this study. The blood samples were collected from sinus retro orbital.

\section{Treatment Regime}

Thirty rats were divided into 6 groups and each group consisted of 5 mice, namely:

i. Normal Group: Animal groups without treatment

ii. Negative Control: Rats were induced by an accumulative dose of doxorubicin $15 \mathrm{mg} / \mathrm{kgBW}+\mathrm{Na}-$ CMC suspension

iii. Positive Control: Rats were induced by accumulative dose of doxorubicin $15 \mathrm{mg} / \mathrm{kgBW}+$ suspension of Vitamin E $100 \mathrm{mg} / \mathrm{kgBW}$

iv. Dose 100: Rats were induced by accumulative dose of doxorubicin $15 \mathrm{mg} / \mathrm{kgBW}+$ extract dose of $100 \mathrm{mg} / \mathrm{kgBW}$.

v. Dose 200: Rats were induced by accumulative dose of doxorubicin $15 \mathrm{mg} / \mathrm{kgBW}+$ extract dose of $200 \mathrm{mg} / \mathrm{kgBW}$

vi. Dose 400: Rats induced by accumulative dose of doxorubicin $15 \mathrm{mg} / \mathrm{kgBW}+$ extract dose of 400 $\mathrm{mg} / \mathrm{kgBW}$

Rats were induced by doxorubicin with an accumulative dose of $15 \mathrm{mg} / \mathrm{kgBW}$ for 15 days by giving doxorubicin 5 times in 1 week with a dose of $1 \mathrm{mg} / \mathrm{kgBW}$ intraperitoneally ${ }^{18}$ and also simultaneously given beetroot extract for 15 days. On day $16^{\text {th }}$, the animals were anesthetized and blood samples were collected and determined the (CK-MB) level, Lactate Dehydrogenase (LDH) level, and hematology profile.

\section{Statistical Analysis}

Analysis of the study was performed by ANOVA with Tukey's Multiple Comparison Test. The significance $P$ values were set at 0.05 . The values for all measurements are expressed as the mean $\pm \mathrm{SD}$.

\section{RESULTS AND DISCUSSION \\ Phytochemical Constituent Result of Ethanol Extract Beetroot \\ Phytochemical screening results showed that ethanol extract beetroot positively contains flavonoids,} alkaloids, saponins, tanins, glycosides and steroids/terpenoids (Table-1). 
RASĀYAN J. Chem.

Vol. 13 | No. 2 |973- 978| April - June | 2020

Table-1: Phytochemical Screening Result

\begin{tabular}{c|c|c|c}
\hline No. & Content & Dried Sample & Extract \\
\hline 1. & Flavonoids & + & + \\
\hline 2. & Alkaloids & + & + \\
\hline 3. & Saponins & + & + \\
\hline 4. & Tanins & + & + \\
\hline 5. & Glycosides & + & + \\
\hline 6. & Steroids/Terpenoid & + & + \\
\hline
\end{tabular}

\section{Effect of Beetroot Ethanol Extract on CK-MB, LDH and Hematology Profile}

Beet root showed cardioprotective activity on CK-MB and LDH levels in doxorubicin-induced toxicity. Tables-2 and 3 shows that treatment at a lower dose of $100 \mathrm{mg} / \mathrm{kgBW}$ was significantly different from negative control $(p<0.05)$. Treatment of beetroot ethanol extract showed improvement in most of the hematological parameters compared to doxorubicin-induced group (Table-4).

Table-2: Effect of Beetroot Treatment on CK-MB Level

\begin{tabular}{c|c}
\hline Groups & Mean CK-MB Levels (U/L) \pm SD \\
\hline Normal Control & $660.75 \pm 40.62^{*}$ \\
\hline Negative Control & $1190.5 \pm 41.2$ \\
\hline Vitamin E Control & $608.5 \pm 47.42^{*}$ \\
\hline Beetroot extract at Dose of $100 \mathrm{mg} / \mathrm{kgBW}$ & $1101.75 \pm 45.93^{*}$ \\
\hline Beetroot extract at Dose of $200 \mathrm{mg} / \mathrm{kgBW}$ & $840.5 \pm 41.27^{*}$ \\
\hline Beetroot extract at Dose of $400 \mathrm{mg} / \mathrm{kgBW}$ & $796.5 \pm 52.61^{*}$ \\
\hline
\end{tabular}

Data expressed as mean \pm SD $(n=6)$

${ }^{*}$ Significant Difference Vs. Negative Control Group at $p<0.01$

Table-3: Effect of Beetroot Treatment on LDH Level

\begin{tabular}{c|c}
\hline Groups & Mean LDH Levels (U/L) \pm SD \\
\hline Normal Control & $1453 \pm 189.27^{*}$ \\
\hline Negative Control & $4811 \pm 785.38$ \\
\hline Vitamin E Control & $2502.2 \pm 138.87^{*}$ \\
\hline Beetroot extract at Dose of $100 \mathrm{mg} / \mathrm{kgBW}$ & $3493.6 \pm 169.85^{*}$ \\
\hline Beetroot extract at Dose of $200 \mathrm{mg} / \mathrm{kgBW}$ & $2665.2 \pm 99.03^{*}$ \\
\hline Beetroot extract at Dose of $400 \mathrm{mg} / \mathrm{kgBW}$ & $2451 \pm 148.73^{*}$ \\
\hline
\end{tabular}

Data expressed as mean \pm SD $(n=6)$

*Significant Difference Vs. Negative Control Group at $p<0.01$

Beetroot extract $(100 \mathrm{mg} / \mathrm{kg})$ co-treated rats showed significant $(p<0.01)$ improvement in most of the hematological parameters compared to doxorubicin-induced group These observations were confirmed by an increased level of WBC, RBCs, HGB, HCT, MCV, MCH, and platelets counts (Table-4).

Table-4: Effect of Beetroot Extract Treatment on Hematology Profile.

\begin{tabular}{l|l|l|l|l|l|l}
\hline \multirow{2}{*}{ Parameters } & \multicolumn{6}{|c}{ Groups (Mean Value \pm SD) } \\
\cline { 2 - 7 } & $\begin{array}{l}\text { Normal } \\
\text { Control }\end{array}$ & $\begin{array}{l}\text { Negative } \\
\text { Control }\end{array}$ & $\begin{array}{l}\text { Vitamin E } \\
\text { Control }\end{array}$ & $\begin{array}{l}\text { Beetroot } \\
\text { extract }(100 \\
\mathrm{mg} / \mathrm{kgBW})\end{array}$ & $\begin{array}{l}\text { Beetroot extract } \\
(100 \mathrm{mg} / \mathrm{kgBW})\end{array}$ & $\begin{array}{l}\text { Beetroot extract } \\
(100 \mathrm{mg} / \mathrm{kgBW})\end{array}$ \\
\hline $\begin{array}{l}\mathrm{WBC} \\
\left(10^{3} / \mathrm{uL}\right)\end{array}$ & $6 \pm 2.07^{*}$ & $1.64 \pm 0.39$ & $4.98 \pm 2.23^{*}$ & $3.54 \pm 2.53^{*}$ & $4.12 \pm 2.40^{*}$ & $4.24 \pm 0.34^{*}$ \\
\hline $\begin{array}{l}\mathrm{RBC} \\
\left(10^{6} / \mathrm{uL}\right)\end{array}$ & $\begin{array}{l}11.032 \pm \\
1.63^{*}\end{array}$ & $5.1 \pm 0.36$ & $8.764 \pm 1.54^{*}$ & $8.162 \pm 0.81^{* *}$ & $8.468 \pm 0.57^{*}$ & $8.582 \pm 0.58^{*}$ \\
\hline $\begin{array}{l}\mathrm{HGB} \\
(\mathrm{g} / \mathrm{dL})\end{array}$ & $\begin{array}{l}12.36 \pm \\
1.91^{*}\end{array}$ & $9.14 \pm 0.60$ & $13.47 \pm 2.23^{*}$ & $11.34 \pm 1.27^{*}$ & $13.08 \pm 0.46^{*}$ & $14.26 \pm 1.31^{*}$ \\
\hline $\mathrm{HCT}(\%)$ & $\begin{array}{l}51.6 \pm \\
4.50^{*}\end{array}$ & $31.14 \pm 1.90$ & $49.47 \pm 8.79^{*}$ & $42.18 \pm 3.13^{*}$ & $45.2 \pm 3.68^{*}$ & $47.15 \pm 2.18^{*}$ \\
\hline $\mathrm{MCV}(\mathrm{fL})$ & $\begin{array}{l}48.23 \pm \\
1.44^{*}\end{array}$ & $39.2 \pm 3.27$ & $45.65 \pm 3.47^{*}$ & $43.16 \pm 1.96^{*}$ & $45.16 \pm 1.23^{*}$ & $45.95 \pm 1.41^{*}$ \\
\hline
\end{tabular}


RASĀYAN J. Chem.

Vol. 13 | No. 2 |973 - 978| April - June | 2020

\begin{tabular}{l|l|l|l|l|l|l}
\hline $\mathrm{MCH}(\mathrm{pg})$ & $\begin{array}{l}13.54 \pm \\
0.69^{*}\end{array}$ & $10.54 \pm 1.29$ & $13.58 \pm 0.54^{*}$ & $13.24 \pm 0.15^{*}$ & $14.17 \pm 0.35^{*}$ & $14.12 \pm 0.31^{*}$ \\
\hline $\begin{array}{l}\mathrm{MCHC} \\
(\mathrm{g} / \mathrm{dL})\end{array}$ & $\begin{array}{l}32.23 \pm \\
1.25^{*}\end{array}$ & $24.93 \pm 2.16$ & $26.32 \pm 0.81$ & $24.22 \pm 1.16$ & $26.18 \pm 1.86$ & $26.9 \pm 0.99^{*}$ \\
\hline $\begin{array}{l}\text { PLT } \\
\left(10^{3} / \mathrm{uL}\right)\end{array}$ & $\begin{array}{l}112.2 \pm \\
133.22^{*}\end{array}$ & $594.4 \pm 14.37$ & $\begin{array}{l}1004.6 \pm \\
132.84^{*}\end{array}$ & $863 \pm 103.18^{*}$ & $9033.4 \pm 118.18^{*}$ & $9095.6 \pm 39.07^{*}$ \\
\hline NEU (\%) & $\begin{array}{l}8.6 \pm \\
4.47^{*}\end{array}$ & $35.6 \pm 4.13$ & $7.4 \pm 4.72^{*}$ & $10 \pm 11.55^{*}$ & $7.8 \pm 2.13^{*}$ & $7.5 \pm 1.58^{*}$ \\
\hline $\begin{array}{l}\text { LYMP } \\
(\%)\end{array}$ & $\begin{array}{l}76.3 \pm \\
7.36^{*}\end{array}$ & $45.4 \pm 3.47$ & $72.1 \pm 1.77^{*}$ & $55.8 \pm 11.12^{*}$ & $63.5 \pm 3.19^{*}$ & $71 \pm 3.19^{*}$ \\
\hline $\begin{array}{l}\text { MONO } \\
(\%)\end{array}$ & $\begin{array}{l}6.8 \pm \\
4.17\end{array}$ & $5.2 \pm 0.83$ & $7.8 \pm 7.13^{*}$ & $6 \pm 7.03$ & $6.8 \pm 1.48$ & $6 \pm 1.13$ \\
\hline EOS (\%) & $0.4 \pm 0.1$ & $1.4 \pm 0.2$ & $1.1 \pm 0.1$ & $1.3 \pm 0.1$ & $1.2 \pm 0.2$ & $1.1 \pm 0.1$ \\
\hline BAS (\%) & $\begin{array}{l}8.7 \pm \\
3.78\end{array}$ & $9 \pm 2.23$ & $9.3 \pm 7.76$ & $14.8 \pm 3.34$ & $12 \pm 3.46$ & $11.2 \pm 1.82$ \\
\hline
\end{tabular}

Data expressed as mean \pm SD $(n=6)$

"Significant Difference Vs. Negative Control Group at $p<0.01$

Creatinine kinase (CK) is an enzyme that is found in heart muscle and skeletal muscle damage. Creatinine kinase is a dimeric molecule consisting of a pair of different monomers namely $\mathrm{MM}, \mathrm{MB}$, and $\mathrm{BB}^{19}$. CK$\mathrm{MB}$ is a heart muscle that can increase if there is cell damage in heart muscle ${ }^{20}$. Lactate dehydrogenase $(\mathrm{LDH})$ is an intracellular enzyme found in almost all metabolized cells. LDH with the highest concentration is found in the heart, skeletal muscle, liver, kidney, brain, and blood cells. The increase of LDH level in serum suggests an increased oxygen demand ${ }^{21}$. Other conditions that can cause increased LDH serum include hypoxia, tissue injury, and necrosis ${ }^{22-23}$. These experimental results also showed a toxic effect of doxorubicin in hematology parameters.

Many studies have been reported the role of medicinal plants in inhibiting the cardiotoxic effect ${ }^{24-26}$. The antioxidant activity might play a role in the cardioprotective effect by inhibiting ROS. Beetroot contains specific compounds namely betanin which is a red pigment in beetroot, beetroot also contains some phytochemical compound in the form of tannins saponins, alkaloids, flavonoids, terpenoids and steroids. Betanin has the antioxidant activity ${ }^{27}$. Betanin is a heterocyclic compound found in beetroot (Beta vulgaris L.), is showed its red-violet pigment ${ }^{28,29}$. The antioxidant activity of betanin is in the presence of cyclic amine groups and hydroxyl, which are hydrogen and electron donors, with the efficacy to stabilize the reactive species ${ }^{30}$. This shows that betanin is a powerful antioxidant that can prevent ROS (Reactive oxygen species) free radical reactions caused by doxorubicin interactions which can cause lipid profile abnormality. The content of other antioxidants such as flavonoids and tannin which is a group of polyphenol also plays a role in improving the condition of rats which were induced by doxorubicin. Flavonoids can reduce CK-MB and LDH reduce the oxidative stress of macrophages by inhibiting cellularly oxygenated and activating cellular antioxidants ${ }^{31}$. Thus, flavonoids and tannins are natural antioxidants that can protect against Reactive oxygen species.

\section{CONCLUSION}

Beetroot ethanol extract has cardioprotective activity in rats that are induced by doxorubicin and it showed dose-dependent.

\section{ACKNOWLEDGMENT}

The research was funded by the Universitas Sumatera Utara by the USU TALENTA Research implementation contract for the fiscal year 2019 Number: 4167 / UN.5.1.R / PPM / 2019 dated April, 1 2019. Each author has a different contribution, for the conception and design of the study was Sony Eka Nugraha. The acquisition of data was Yuandani, analysis and interpretation of data were Embun Suci Nasution and Rony Abdi Syahputra.

\section{REFERENCES}

1. A. De Angelis, K. Urbanek, D. Cappetta, E. Piegari, L. P. Ciuffreda, A. Rivellino, R. Russo, G. Esposito, F. Rossi, and L. Berrino, Cardio-Oncology, 2(1),1(2016), DOI:10.1186/s40959-016-00124. 


\section{RASĀYAN J. Chem.}

Vol. 13 | No. 2 |973 - 978| April - June | 2020

2. S. Christiansen and R. Autschbach, European Journal of Cardio-Thoracic Surgery, 30(4), 611(2006), DOI:10.1016/j.ejcts.2006.06.024.

3. M. Ilie and D. Margin, 2012, Trends in the Evaluation of Lipid Peroxidation Processes, In: Lipid Peroxidation, IntechOpen Limited., London, DOI:10.5772/46075.

4. P. Singal, T. Li, D. Kumar, I. Danelisen, and N. Iliskovic, Molecular and Cellular Biochemistry, 207(1), 77(2000), DOI:10.1023/a:1007094214460.

5. J. Ghosh, J. Das, P. Manna and P.C. Sil, Biomaterials, 32(21), 4857(2011), DOI:10.1016/j.biomaterials.2011.03.048.

6. C. F. Thorn, C. Oshiro, S. Marsh, T. Hernandez-Boussard, H. McLeod, T. E. Klein, and R. B. Altman, Pharmacogenetics and Genomic, 21(7), 440(2011), DOI:10.1097/fpc.0b013e32833ffb56.

7. J. R. Prohaska, The Journal of Nutrition, 121(3), 355(1991), DOI:10.1093/hmg/5.2.283.

8. A. Pugazhendhi, T. N. J. I. Edison, B. K. Velmurugan, J. A. Jacob, and I. Karuppusamy, Life Sciences, 200 (1), 26(2018), DOI: 10.1016/j.lfs.2018.03.023.

9. T. Murata, H. Yamawaki, M. Hori, K. Sato, H. Ozaki, and H. Karaki, British Journal of Pharmacology, 132(7), 1365(2001), DOI:10.1038/sj.bjp.0703959.

10. J. Zhan, Journal of Molecular and Cellular Cardiology, 28(9), 1931(1996), DOI: 10.1006/jmcc.1996.0186.

11. J. Dudka, R. Gieroba, A. Korga, F. Burdan, W. Matysiak, B. Jodlowska-Jedrych, S. Mandziuk, E. Korobowicz, and M. Murias, Evidence-Based Complementary and Alternative Medicine. 12, 1(2012) DOI: $10.1155 / 2012 / 606183$.

12. G. Georgiev, J. Weber, E.-M. Kneschke, P. N. Denev, T. Bley, and A. I. Pavlov, Plant Foods for Human Nutrition, 65(2), 105(2010), DOI:10.1007/s11130-010-0156-6.

13. S. S. El-Hawary, F. M. Hammouda, W. A. Tawfik, H. A. Kassem, K. A. Abdelshafeek and S. S. ElShamy, Rasayan Journal of Chemistry,10(4), 1391(2017), DOI:10.7324/rjc.2017.1041936.

14. P. Sugita, S.Arya, A. Ilmiawati and B.Arifin, Rasayan Journal of Chemistry, 10(3), 707(2017), DOI: $10.7324 /$ rjc. 2017.1031766.

15. R. I. Depkes, Materia Medika, 6th Edition, Ditjen POM, Jakarta, p. 297 (1995).

16. N.R. Farnsworth, Journal of Pharmaceutical Sciences, 55(3), 225(1996).

17. Taiwo F. Owoeye, Olayinka Oyewale Ajani, Deborah K. Akinlabu and O. I. Ayanda, Rasayan Journal of Chemistry, 10(3), 907(2017), DOI:10.7324/rjc.2017.1031712.

18. R. V. Santos, M. L. Batista, É. C. Caperuto, and L. F. Costa Rosa, Clinical and Experimental Pharmacology and Physiology, 34(12), 1294(2007), DOI:10.1111/j.1440-1681.2007.04717.x .

19. J. Kim and I. A. Hashim, Clinica Chimica Acta, 456, 89(2016), DOI:10.1016/j.cca.2016.02.030.

20. T. Kawada, Journal of Cardiology, 73(4), 333(2019), DOI:10.1016/j.jjcc.2018.11.014.

21. O. Carvajal-Zarrabal, P. M. Hayward-Jones, C. Nolasco-Hipolito, D. M. Barradas-Dermitz, A. L. Calderón-Garcidueñas, and N. López-Amador, Journal of Forensic Sciences, 62(5), 1332(2017), DOI:10.1111/1556-4029.13397.

22. L. Sharma, A. K. Verma, A. Rahal, A. Kumar, and R. Nigam, Biotechnology, 15(3), 96(2016), DOI: 10.3923/biotech.2016.96.100.

23. C. J. Valvona, H. L. Fillmore, P. B. Nunn, and G. J. Pilkington, Brain Pathology, 26(1), 3(2015), DOI:10.1111/bpa.12299.

24. G. Drevenšek, M. Lunder, E. T. Benković, B. Štrukelj, and S. Kreft, Food \& Nutrition Research, 60(1), 29623(2016), DOI:10.3402/fnr.v60.29623.

25. B. N. R., K. K. Prasanna, K. H. Prakash, P. Himadri S., K. Arvind, B. Sanjib, and K. H. Pallab, Chinese Journal of Natural Medicines, 11(1), 38(2014), DOI:10.5220/0008359701900193.

26. M. H. Tarigan, U. Harahap, A. Dalimunthe, and N. Nerdy, Asian Journal of Pharmaceutical and Clinical Research, 11(9), 165 (2018), DOI:10.22159/ajpcr.2018.v11i9.26907.

27. D. Vieira Teixeira da Silva, D. dos Santos Baião, F. de Oliveira Silva, G. Alves, D. Perrone, E. Mere Del Aguila, and V. M. Flosi Paschoalin, Molecules, 24(3), 458(2019), DOI: 10.3390/molecules24030458.

28. D.B Rodriguez-Amaya DB, Natural Food Pigments and Colorants, Bioactive Molecules in Food, Springer, New York, p.867-901(2019). 
RASĀYAN J. Chem.

Vol. 13 | No. 2 |973 - 978| April - June | 2020

29. I. Račkauskienė, A. Pukalskas, P. R. Venskutonis, A. Fiore, A. D. Troise, and V. Fogliano, Food Research International, 70, 31(2015), DOI:10.1016/j.foodres.2015.01.026.

30. Y. Zhao and M. D. Pluth, Angewandte Chemie, 128(47), 14858(2016), DOI:10.1002/ange.201608052.

31. K. S. Al-Numair, G. Chandramohan, and M. A. Alsaif, Journal of Natural Medicines, 66(1), 95 (2011), DOI:10.1007/s11418-011-0558-2.

[RJC-5601/2019] 